INSIGHTS INTO REGIONAL DEVELOPMENT

ISSN 2669-0195 (online) http://jssidoi.org/IRD/

2020 Volume 2 Number 2 (June)

http://doi.org/10.9770/IRD.2020.2.2(7)

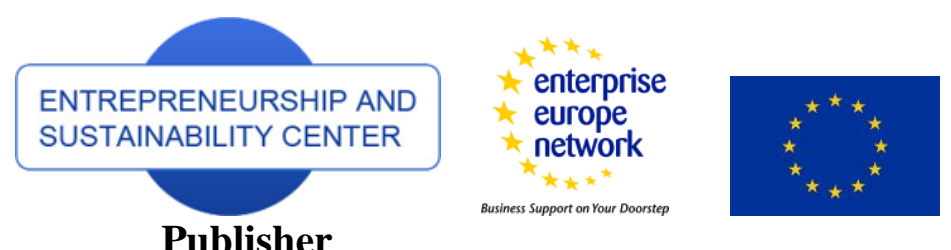

http://jssidoi.org/esc/home

\title{
IMPACT OF INFORMATION TECHNOLOGY ON STRATEGIC MANAGEMENT IN THE BANKING SECTOR OF IRAQ*
}

\author{
Adetayo Olaniyi Adeniran ${ }^{1}$, Hamid Mohsin Jadah ${ }^{2}$, Noor Hashim Mohammed ${ }^{3}$ \\ ${ }^{I}$ Department of Transport Management Technology, of the Federal University of Technology Akure, Nigeria \\ ${ }^{2}$ Department of Finance and Banking, College of Administration and Economics, University of Kerbala, Iraq \\ ${ }^{3}$ Department of Finance and Banking, Imam AL-Kadhum College for Islamic Studies, Babylon Department, Iraq \\ E-mails:.' adeniranao@futa.edu.ng, ${ }^{2}$ hamed.m@uokerbala.edu.iq, ${ }^{3}$ noor-hashim136@gmail.com
}

Received 15 February 2020; accepted 10 April 2020; published 30 June 2020

\begin{abstract}
The main objective of the study is to examine the impact of information technology on strategic management in the banking sector. The specific objectives are to identify the applications of information technology in banking sector; to examine the association between education level and customer's usage of IT applications in the banking sector; and to examine the relationship between information technology and organization's strategy. The methodology of the study is supported by interview of bank customers and interview of industry experts based on purposive sampling technique. The findings revealed that Electronic cards, ATMs, online banking, electronic payment, and mobile banking were the major application of IT in Iraq banking sector. There is an association between education level of bank customers and their usage of IT applications regarding banking transactions in Iraq. There is a relationship between information technology and organization's strategy which has resulted in value creation and competitive advantage of banks. It was recommended that for better performance of IT on banking, the management of banking sector should adopt better policies that will encourage users to adopt IT usage in banks. The main contribution of this study is that information technology enhances value creation and competitive advantage in Iraq banks.
\end{abstract}

Keywords: information technology; banking sector; strategic management; IT

Reference to this paper should be made as follows: Adeniran, A.O., Jadah, H. M, Mohammed, N. H. 2020. Impact of information technology on strategic management in the banking sector of Iraq. Insights into Regional Development, 2(2), 592-601. https://doi.org/10.9770/IRD.2020.2.2(7)

\footnotetext{
* This research was partly supported by the project, which has received funding from the European Union's Horizon 2020 research and innovation programme European Research Council (ERC) under the European Union's Horizon 2020 research and innovation programme Grant Agreement Number (H2020 - INT-INCO-2014 - INT-02-2014)
}
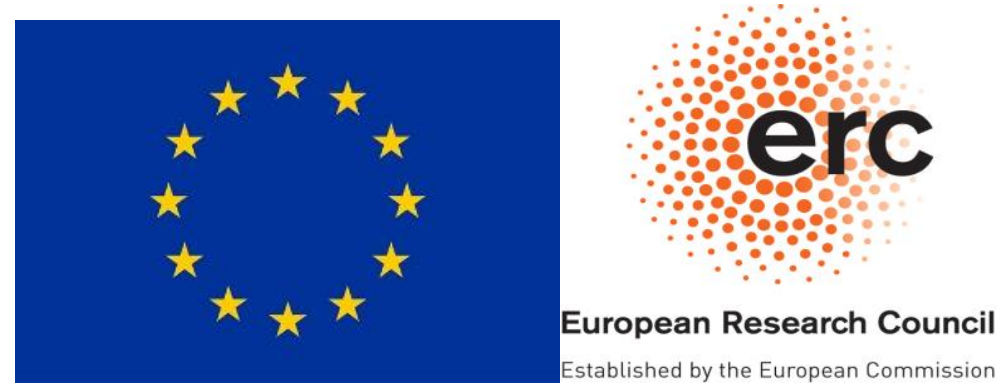
JEL Classifications: O30, O32, O53

Additional disciplines: information and communication

\section{Introduction}

The evidence of information technology (IT) has become real in the $21^{\text {st }}$ century. Information technology is encapsulation of computer and telecommunication application that is used for storing, transmitting and sending, retrieving and processing data. IT is an essential part of organizational life as it has become life wire for success of any organization (Huber, 1990). Strategic management has been identified as the systemic process of identifying internal and external factors of an organization to describe improved organizational objectives. Strategic management enhances value creation and competitive advantage for the purpose of maximizing profit and minimizing cost.

In the recent time, organizations cannot create value nor achieve competitive advantage without adopting information technology. Evolvement of information technology saves time and monetary cost, and enhances data security. The processes of data collection and storage within an organization were initially challenging before the prevalent usage of computers. The advent of information technology was evidenced by the dominance of computer system, and it has become possible for strategic managers to select relevant information without wasting time. Reddy, Srinivasu, Rikkula, and Rao (2009) noted that most organizations now rely on information technology as it often enhances organization's success. In fact, Keen (1981) perceived that information technology has become the backbone for organization.

The $21^{\text {st }}$ century is a globalized era that is much reliant on information technology across all sectors. Also, organizations have relied more on information technology such that it will be very hard for business to thrive without IT. Before the dominance of information technology, large organizations were known for implementing information technology but now both large and mini organizations now implement information technology.

The aim of this study is to examine the impact of information technology on strategy management with emphasis on Iraq banking industry. The specific objectives are to:

i.identify the applications of information technology in banking sector;

ii.examine the association between education level and customer's usage of IT applications in the banking sector; and

iii. examine the relationship between information technology and organization's strategy in Iraq banks.

\section{Literature Review}

\subsection{Information technology}

Information technology implies computers, ancillary equipment, software and hardware, procedures, services (including support services) and related resources. It also includes any equipment or interconnected system or subsystem of equipment, which is used in the automatic acquisition, storage, manipulation, management, movement, control, display, switching, interchange, transmission or reception of data or information (Adeniran, 


\section{INSIGHTS INTO REGIONAL DEVELOPMENT}

ISSN 2669-0195 (online) http://jssidoi.org/IRD/

2020 Volume 2 Number 2 (June)

http://doi.org/10.9770/IRD.2020.2.2(7)

2016). IT is set of technologies which creates, communicates, acquires, analyzes, saves and transmits information and data (Breznik, 2012). Information technology has become an essential part for any organization's success in today's globalized era. Zuboff (1985) stated that information technology is the computer mediated work where a task is accomplished through the medium of the information system rather than through direct physical contact with the task.

Information technology is required for any organizations success in today's world to gain competitive advantage (Hemmatfar, Salehi, and Bayat, 2010). There seems to be no aspect of human life which remains unaffected by information technology in the recent times. Businesses are carried out in global environment mostly because of the singular factor of IT, and it may be difficult to serve businesses without information technology.

Two basic opposing views exist with regard to the impact of information technology on individuals. In the study of Zuboff, information technology is categorized based on the category of tools involved. There are two major categories, they are:

\section{i. Automated and}

ii.Informated

An automated technology seems to deskill the processes that make up the work. This type of technology requires greater control and continuity over the work process, and it can be achieved by substituting technology for human labor with automated devices (Zuboff, 1988). While informated technology, on the other hand, is designed to upgrade or enrich the work processes. Informated technology enhances the removal of most boring, repetitious, dangerous and mindless tasks from the work. Therefore human labor is left to perform the creative, challenging, intellectual and satisfying aspects of the task (Zuboff, 1988).

\subsection{Information technology in the banking sector}

Provision of quality services to customers is not adequate to create value and achieve competitive advantage over its competitor's. Organizations needed to be more creative, fast and dynamic. Without stressing the essentials, organizations should be more strategic in decision making, and devise better approaches to communicate with customers through information technology. According to Oluwatolani, Joshua, and Philip (2011), internet has become an integral part of human living. Its usage has positively enhanced the adoption of various banking solutions such as online banking.

Competitive advantage has manifested through e-banking in the banking sector. Customers have become even smarter, and their preferences are changing day-by-day. This changing preference of customers makes it difficult for customers to accept average service delivery instead of the demand for excellent services. Customers are the major determinant of what will happen to service providers, that is why they are referred to as king of market. On this note, banks endeavour to retain their customers by providing them excellent services for the purpose of realizing customer retention and customer loyalty. According to Uppal (2011), information technology has become necessary for business survival in the global era.

\subsection{Impacts of information technology in banking sector}

Oluwatolani, Joshua, and Philip (2011) perceived that e-banking is carrying out banking transactions on electronic devices as it increases efficiency, speeds up delivery timings, made transactions easier with smooth flow of information, checks fraudulent, immediate responses, reduces errors, provides better quality services etc. Information technology has enhanced the usage of ATM (which enables customers to dispense cash at any point 


\section{INSIGHTS INTO REGIONAL DEVELOPMENT}

ISSN 2669-0195 (online) http://jssidoi.org/IRD/

2020 Volume 2 Number 2 (June)

http://doi.org/10.9770/IRD.2020.2.2(7)

of time regardless of traditional banking hours for services like transfer of funds, payment of utility bills, mini statements, etc), online banking services (enhances customers to perform all their transactions electronically without any physical flow of cash), electronic transfer of funds without issue, internet banking service (for paying bills, transfer funds, check balance statements and perform online transactions electronically), electronic mail (for solving communication issues between banks, customers, organizations and other parties), telephone banking (which enhances transaction via telephone), etc. All these are the benefits of information technology to banking sector.

The review of important literature shows that there are limited studies in the adoption of information technology in banking sector of developing countries. Despite the discussions and affirmation of the impacts of information technology on strategic management in the banking sector, the extent of usage among customers which may often be influenced by their level of education may not have been properly captured. In view of this, the present study delved into the identification of information technology application in the banking sector; determination of the education level of bank customers; and examination of the customer's usage level of IT applications in banking sector. It is believed that this approach is capable of giving a plausible result in the regard.

\section{Methodology}

Primary data was employed to achieve descriptive statistics. The data was obtained from bank officials and bank customers in Iraq. Questionnaires were designed and distributed for the period of six months through nonprobability (purposive) sampling technique. The primary data was collected from $15^{\text {th }}$ March to $14^{\text {th }}$ May 2019 from bank customers who must have experienced the banking services offered by selected banks, and bank officials in Iraq. The study was subjected to subjective criteria, and Statistical Package for Social Science (SPSS) version 20 for Windows 10 was employed for the data entry and data analysis.

The study employs non-probability (purposive) sampling technique; it is a type of non-probability sampling that involves the sample being drawn from part of the population that is close to hand or easy to reach. This technique was adopted because the total population was large, unidentified (Hafaz, Thurasamy, Aziz, Ali and Khan, 2019), and uncertain population that were available in the banking area as at the time of administering the questionnaires. Because of the uncertain number of population in the banking premises at a particular time, judgment was made about the confidence level and the maximum error allowance (Zikmund, 1999). The error allowance was 0.04 based on the discretion of the researcher. The formulae for achieving sample size $n=z^{2} / 4 E^{2}$

where;

$\mathrm{n}=$ Sample sizes for the airport terminal;

$\mathrm{Z}=\mathrm{Z}$ score for the confidence interval 2.05;

$\mathrm{E}=$ Error allowance 0.04 .

The sample size was approximated to 657 respondents which included the bank officials and bank customers.

\section{Response Rate of Respondents}

The study sought to gather information from bank officials and bank customers. A total of six hundred and fifty seven (657) questionnaires were distributed and 502 questionnaires were collected having been filled completely. According to Mugenda and Mugenda (2003), a response rate of 50 percent is adequate for data analysis and reporting; a rate of 60 percent is good and a response rate of 70 percent and over is excellent, this implies that an 
INSIGHTS INTO REGIONAL DEVELOPMENT

ISSN 2669-0195 (online) http://jssidoi.org/IRD/

2020 Volume 2 Number 2 (June)

http://doi.org/10.9770/IRD.2020.2.2(7)

approximate of 76.4 percent response rate for this study was suitable for data analysis and reporting (see Table 1). From the same table, questionnaire administration targeted at bank customers and bank officials was carried out for two months. Out of five hundred and two (502) valid questionnaires retrieved, one hundred and fifty seven (157) questionnaires were retrieved from bank officials while three hundred and forty five (345) questionnaires were retrieved from bank customers.

Table 1. Response rate of questionnaires administered to respondents

\begin{tabular}{|c|c|c|c|c|}
\hline Banks & Questionnaires & Administered & Questionnaires Retrieved & Percentage Retrieved \\
\hline Total & 657 & & 502 & 100.0 \\
\hline
\end{tabular}

Source: Authors' work (2020)

\section{Results and Discussions}

This study is set to examine the impact of information technology on strategy management with emphasis on Iraq banking industry. Regarding the application of IT in banking sector, questions were asked from bank officials. The following: electronic cards, ATMs, online banking, electronic payment, and mobile banking were listed to be the major application of IT in banking sector.

The second objective set to determine the association between education level of bank customers and their usage of IT applications regarding banking transactions. Education indicators are SSCE, NCE, OND, HND/BSc, while banking transactions applied by IT applications with respect to frequency of transactions. This was analyzed with Chi Square test. (See Tables 2 and 3)

Table 2. Contingency table showing the cross tabulation of education level and usage of IT on bank transactions

\begin{tabular}{|l|lll|l|}
\hline Education/Usage & HND/BSc (\%) & NCE/OND & SSCE & TOTAL (\%) \\
\hline Frequently & 15 & 1.9 & 1 & $\mathbf{1 7 . 9}$ \\
Occasionally & 10 & 17 & 8 & $\mathbf{3 5}$ \\
Rarely & 2.1 & 22 & 8 & $\mathbf{3 2 . 1}$ \\
No & 4 & 7 & 4 & $\mathbf{1 5}$ \\
\hline TOTAL & $\mathbf{3 1 . 1}$ & $\mathbf{4 7 . 9}$ & $\mathbf{2 1}$ & $\mathbf{1 0 0}$ \\
\hline
\end{tabular}

Source: Authors' Survey

The Chi-Square distribution is a theoretical or mathematical distribution which has wide applicability in statistical analysis. The term 'Chi Square' (pronounced with a hard 'ch') is used because the Greek letter $\chi$ is used to define this distribution. It can be seen that the elements on which this distribution is based are squared, so that the symbol $\chi^{2}$ is used to denote the distribution (Stephanie, 2018; Adeniran, 2018).

The Chi Square statistic is commonly used for testing relationships between categorical variables. The null hypothesis of the Chi Square test is that no relationship exists with the categorical variables in the population; they are independent. Also, it is commonly used to evaluate tests of independence when using a cross tabulation (also known as a bivariate table). Cross tabulation presents the distributions of two categorical variables simultaneously, with the intersections of the categories of the variables appearing in the cells of the table (Adeniran, 2018).

The Test of independence assesses whether an association exists between the two variables by comparing the observed pattern of responses in the cells to the pattern that would be expected if variables were truly independent 
of each other (Stephanie, 2018; Adeniran, 2018). In the same vein, $\chi 2$ statistic appears quite different from the other statistics because it can be used for achieving the goodness of fit test and the test of independence. For both of these tests, the data obtained from the sample are referred to as the observed numbers of cases. These are the frequencies of occurrence for each category into which the data have been grouped (Adeniran, 2018).

At 0.05 critical regions (significance level), determine the table value when the Degree of Freedom is $(R-1)(C-1)$. Where $\mathrm{R}$ is the row and $\mathrm{C}$ is the column. Degree of freedom $=(4-1)(3-1)=6$. At 0.05 significance level, the degree of freedom 6 gives a table value of 12.59. To compute the test statistics using Chi-square test; $\Sigma\left[(O-E)^{2}\right.$ $\div E]$

Table 3. Chi Square test

\begin{tabular}{|l|l|l|l|l|}
\hline Observed $(\mathrm{O})$ & Expected $(\mathrm{E})$ & $\mathrm{O}-\mathrm{E}$ & $(\mathrm{O}-\mathrm{E})^{2}$ & $(\mathrm{O}-\mathrm{E})^{2} \div \mathrm{E}$ \\
\hline 15 & 5.57 & 9.43 & 88.93 & 15.97 \\
\hline 1.9 & 8.57 & -6.67 & 44.49 & 5.19 \\
\hline 1 & 3.76 & -2.76 & 7.62 & 2.03 \\
\hline 10 & 10.89 & -0.89 & 0.79 & 0.07 \\
\hline 17 & 16.77 & 0.23 & 0.05 & 0.00 \\
\hline 8 & 7.35 & 0.65 & 0.42 & 0.06 \\
\hline 2.1 & 9.98 & -7.88 & 62.09 & 6.22 \\
\hline 2.2 & 15.38 & 6.62 & 43.82 & 2.85 \\
\hline 8 & 6.74 & 1.26 & 1.59 & 0.24 \\
\hline 4 & 4.67 & -0.67 & 0.45 & \\
\hline 7 & 7.19 & -0.19 & 0.04 & 0.10 \\
\hline 4 & 3.15 & 0.85 & 0.72 & 0.01 \\
\hline
\end{tabular}

Source: Authors' Survey

Hence, Chi-square test is 32.97. It can be noted that the computed value is 32.97 is greater than table value 12.59; hence, there is a basis to affirm the association between education level of bank customers and their usage of IT applications regarding banking transactions in Iraq. When comparing the observed and the expected lines in the figure, we can deduce that the fitness or goodness between the two lines is fair. This can be attributed to the nature of sample.

The third objective examines the relationship between information technology and organization's strategy in banking sector. Information technology in banking sector was captured with the usage of ATMs and mobile banking, while organization strategy in banking sector was captured with value created and competiveness among banks. Questions were asked from bank customers on the usage of ATMs and mobile banking. From the survey, it was revealed that 87 percent of respondents do make use of ATMs and 41 percent of respondents do make use of mobile banking option. From the bank officials surveyed, it was revealed that the use of ATMs and mobile banking resulted to bank value creation and competitiveness.

This study confirmed that information technology in banking do enhance strategic management. In fact, banking sector in the $21^{\text {st }}$ century is centred on information technology with high consciousness of all principles in strategic management. Information technology has changed manual system of banking to the use of sophisticated software that even requires highly skilled personnel to handle on the part of the organization while user friendly on the part of the customers. Works that were initially done manually are now done with the use of computer software. This enhances several tasks involving huge steps and numerical analysis to be carried out within the twinkle of an eye. 


\section{INSIGHTS INTO REGIONAL DEVELOPMENT}

ISSN 2669-0195 (online) http://jssidoi.org/IRD/

2020 Volume 2 Number 2 (June)

http://doi.org/10.9770/IRD.2020.2.2(7)

In reality, banks now communicate with each other and with customers through information technology. What is required is proper networking which is achieved through the linkage of information technology and personal computers from one point to another through fibre optics from central server. Banks can assess and have share customers' data through IT. As a result of this information technology has been recognized as the backbone of banking sector. All the activities in the bank are now dependent on information technology. The funniest thing is that bank entrance is secured by information technology. Data management is not taken crucial as it will be used for prediction of future happenings and critical decisions.

Information technology enhances the manufacture of meaningful information that is used in making effective decisions, thereby fulfilling the mandate of management needs such as problem solving and decision making. Information technology also enhances the quick processing of mathematical and statistical analysis in an efficient manner. It can therefore be affirmed that there is an association between information technology and the management of organization's strategic process. Information technology enhances accuracy, increased productivity, work minimization, efficiency, less wastage, more production, customer retention, customer satisfaction, satisfaction surveys etc. However, the challenge that may arise is ignorance of information technology which may result to fear of job loss.

The study of Ugwu, Oyebisi, Ilori, and Adagunodo (2000) revealed that most bank have their own website on internet to provide users various services which have enhanced transformation from old banking system to modern banking through the adoption of information technology. This study was carried out about 20 years ago. It is pertinent to note that the information technology is changing and not static; hence the impact of information technology on banking sector 20 years ago must have changed in the present era.

The studies of Berisha-Namani (2010), Apulu and Latham (2011), Cakmak and Tas (2012), Madadipouya (2015) agrees with the findings of this study. The study of Berisha-Namani (2010) found that information technology is principally designed to support decision making activities of the management. As the world is drastically changing day by day, it has been evident that no organization can survive without information technology. Apulu and Latham (2011) find that the adoption of IT has huge impact on organizational performance as it is continuous source of growth by increasing efficiency and reducing cost. Information technology enhances efficiency of strategic management in accordance to demand for achieving competitive advantage.

According to Cakmak and Tas (2012), information technology enhances effectiveness and efficiency of strategic management activities which enhances value creation and competitive advantage. It is of no doubt that banks having achieved value creation and competitive advantage which is the aim of strategic management; they have taken advantage of information technology.

In fact, most of the strategies adopted today no longer remains strategic tomorrow because of rapidly changing environment. Among the determinant factors to be considered in the process of strategic management decisions with respect to banking industry are reliability, serviceability, performance, quality of service delivery, ease of usage, durability etc.

Each business has their dynamics of the required IT to be adopted. Madadipouya (2015) stated that IT has enabled diverse organizations to strategically adapt to transformations in business environments. Andersen (2001) also complement that the usage of IT has increased organizational performance, innovation and business profitability, which are all means of achieving competitive advantage. 


\section{INSIGHTS INTO REGIONAL DEVELOPMENT}

ISSN 2669-0195 (online) http://jssidoi.org/IRD/

2020 Volume 2 Number 2 (June)

http://doi.org/10.9770/IRD.2020.2.2(7)

\section{Conclusions}

This study has gaudily explored the impact of information technology on strategic management in the Iraq banking sector. The development and spread in technology have reformed many businesses across the world. Banking industry is no exclusion in the revolution. All the commercial banks of developed countries have adopted information technology in their daily business transactions.

The study examined the impact of information technology on strategy management with emphasis on Iraq banking industry. Electronic cards, ATMs, online banking, electronic payment, and mobile banking were the major application of IT in Iraq banking sector. Also, there is an association between education level of bank customers and their usage of IT applications regarding banking transactions in Iraq. Finally, there is a relationship between information technology and organization's strategy which has resulted in value creation and competitive advantage of banks.

Since information technology has drastically changed the nature of olden day banking system. Acceptance and implementation of IT has been proven crucial for the survival of any bank most especially that many bank users are time conscious and preferring electronic banking than old system of banking because of efficient delivery processes, smooth flow of information, better performances, easier transactions. All these are confirmation that IT has positive impact on banking most especially in Iraq. The high level of internet penetration among the populace makes it possible for the drastic acceptance and adoption of information technology in Iraq banking sector. For better performance of IT on banking, the management of banking sector should adopt better policies that will encourage users to adopt IT usage in banks.

\section{References}

Adeniran, A. O. (2016). Impacts of the Fourth Industrial Revolution on Transportation in the Developing Nations. International Educational Scientific Research Journal, 2(11), 56-60.

Adeniran, A. O. (2018). Establishing chi square as a non-parametric test in descriptive statistics. Science \& Technology, 4, 106-113

Andersen, T. J. (2001). Information technology, strategic decision making approaches and organizational performance in different industrial settings. The Journal of Strategic Information Systems, 10(2), 101-119.

Apulu, I., \& Latham, A. (2011). An evaluation of the impact of Information and Communication Technologies: Two case study examples. International Business Research, 4(3), p3.

Berisha-Namani, M. (2010). The role of information systems in management decision making-an theoretical approach. Manager Journal, 12(1), 109-116.

Breznik, Li. (2012). Can information technology be a source of competitive advantage? Economic and Business Review, 14(3), 251-269.

Cakmak, P. I., \& Tas, E. (2012). The Use of Information Technology on Gaining Competitive Advantage in Turkish Contractor Firms. World Applied Sciences Journal, 18(2), 274-285.

Hafaz, N. A., Thurasamy, R., Aziz, N. A., Ali, H., \& Khan, M. I. (2019). Modelling the Adoption of Halal Warehousing Services among Halal Pharmaceutical and Cosmetic Manufacturers. Journal of Sustainability Science and Management (Vol. 14).

Hemmatfar, M., Salehi, M., \& Bayat, M. (2010). Competitive advantages and strategic information systems. International Journal of Business and Management, 5(7) https://doi.org/10.5539/ijbm.v5n7p158

Keen, P. G. (1981). Information systems and organizational change. Communications of the ACM, 24(1), 24-33. 


\section{INSIGHTS INTO REGIONAL DEVELOPMENT}

ISSN 2669-0195 (online) http://jssidoi.org/IRD/

2020 Volume 2 Number 2 (June)

http://doi.org/10.9770/IRD.2020.2.2(7)

Madadipouya, K. (2015). A Review On The Strategic Use Of IT Applications In Achieving and Sustaining Competitive Advantage. arXiv Preprint arXiv:1507.01233. Retrieved from http://arxiv.org/abs/1507.01233 10.5121/ijmpict.2015.6202

Microsoft ${ }^{\circledR}$ Encarta ${ }^{\circledR}$ 2009. (C) 1993-2008 Microsoft Corporation. All rights reserved.

Mugenda, O. M., \& Mugenda, A. G. (2003). Research Methods: Quantitative and Qualitative Approaches. Acts Press, Nairobi, 2003.

Oluwatolani, O., Joshua, A., \& Philip, A. (2011). The Impact of Information Technology in Nigeria's Banking Industry. arXiv Preprint arXiv:1108.1153. Retrieved from http://arxiv.org/abs/1108.1153

Reddy, G. S., Srinivasu, R., Rikkula, S. R., \& Rao, V. S. (2009). Management information system to help managers for providing decision making in an organization. International Journal of Reviews in Computing, 1-6.

Stephanie (2018). Chi Square Statistics in Research. Retrieved on 17 th January, 2020 from: http://www.statisticssolutions.com/usingChiSquare-statistics-in- research/

Ugwu, L. O., Oyebisi, T. O., Ilori, M. O., \& Adagunodo, E. R. (2000). Organisational impact of information technology on the banking and insurance sector in Nigeria. Technovation, 20(12), 711-721.

Uppal, D. R. (2011). Customer Delight-A milestone for the banks. Journal of Arts, Science and Commerce, 2(4). Retrieved from http://www.researchersworld.com/vol2/issue4/Paper_2.pdf

Zikmund, W. G. (1999). Business Research Methods. Sixth Edition. The Dryden Press Harcourt College Publishers, $389,1999$.

Zuboff, S. (1985). Automate-Informate: The new faces of intelligent technology. Organizational Dynamics, 14, 5-18.

Zuboff, S. (1988). In the Age of the Smart Machine: The Future of Work and Power. New York: Basic Books

\section{Acknowledgement}

This research was partly supported by the project, which has received funding from the European Union's Horizon 2020 research and innovation programme European Research Council (ERC) under the European Union's Horizon 2020 research and innovation programme Grant Agreement Number (H2020 - INT-INCO-2014 - INT-02-2014)
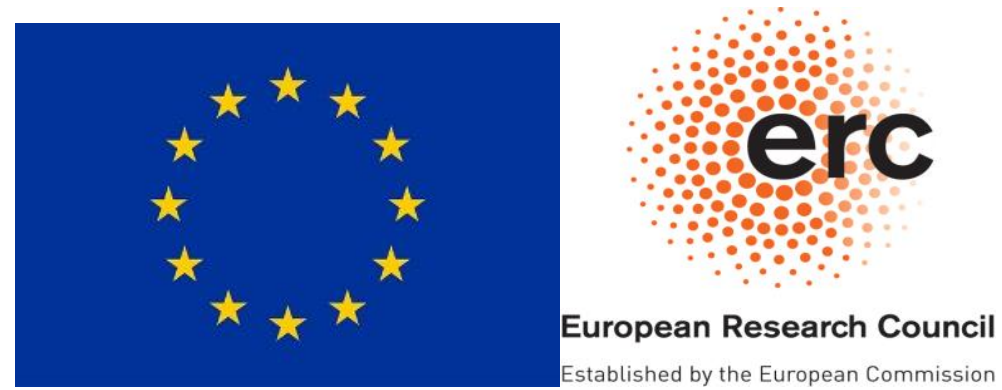


\section{Contributions of Authors}

\begin{tabular}{|l|l|l|}
\hline Name of the Author(s) & $\begin{array}{l}\text { Contribution of } \\
\text { authors (\%) }\end{array}$ & $\begin{array}{l}\text { Description of contribution of authors (concepts, design, } \\
\text { analysis and interpretation of data, methods etc.) }\end{array}$ \\
\hline Adetayo Olaniyi ADENIRAN & 40 & Design and final edited \\
\hline Hamid Mohsin JADAH & 30 & Additional design and proof read \\
\hline Noor Hashim MOHAMMED & 30 & Abstract redesign and proof read \\
\hline
\end{tabular}

Adetayo Olaniyi ADENIRAN is a research expert and the founder of BUTY Global (Project Management and Research Consultancy). ORCID ID: orcid.org/0000-0002-6870-1212

Hamid Mohsin JADAH is a Ph.D holder in the department of Finance and Banking, College of Administration and Economics, University of Kerbala.

ORCID ID: orcid.org/0000-0002-8170-5453

Noor Hashim MOHAMMED is a Ph.D holder in the department of Finance and Banking, Imam AL-Kadhum College for Islamic StudiesBabylon Departments.

ORCID ID: orcid.org/0000-0001-9206-6530

Register for an ORCID ID:

https://orcid.org/register

Copyright (C) 2020 by author(s) and VsI Entrepreneurship and Sustainability Center

This work is licensed under the Creative Commons Attribution International License (CC BY).

http://creativecommons.org/licenses/by/4.0/

c) (i) Open Access 